2004

\title{
Industrial symbiosis: the case for market coordination
}

article version: accepted manuscript

Desrochers, Pierre

Desrochers, P. (2004). Industrial symbiosis: the case for market coordination. Journal of Cleaner Production, 12(8), 1099-1110.

\section{HOW TO CITE TSPACE ITEMS}

Always cite the published version, so the author(s) will receive recognition through services that track citation counts, e.g. Scopus. If you need to cite the page number of the TSpace version (original manuscript or accepted manuscript) because you cannot access the published version, then cite the TSpace version in addition to the published version using the permanent URI (handle) found on the record page. 


\title{
Industrial Symbiosis : The Case for Market Coordination.
}

\author{
Pierre Desrochers \\ Assistant Professor \\ Department of Geography \\ University of Toronto at Mississauga \\ 3359 Mississauga Road North \\ South Building, Room 3107 \\ Mississauga, Ontario \\ Canada L5L 1 C6 \\ Tel: (905) 828-5206 \\ Fax: (905) 828-5273 \\ e-mail: pierre.desrochers@utoronto.ca
}

\section{Summary:}

Despite the fact that all successful documented cases of industrial symbiosis to this day have been self-organizing, some authors and development officials have suggested that increased public planning might deliver better results in this respect than spontaneously evolved market coordination. This paper takes an historical approach to suggest that comprehensive planning is unlikely to live up to the expectations of its proponents.

The essay is structured as follows. The first section provides short case studies of industrial symbiosis in highly different economic and institutional settings, the essentially free-market regime of Victorian England and communist Hungary (1948-1989). The available evidence suggests that market coordination proved much more favorable to the emergence of industrial symbiosis, despite the elaboration of a comprehensive policy to that effect in Hungary. Insights derived from the so-called "Austrian" critique of central planning are then used to explain this paradox. The analysis presented suggests that the Hungarian planners' failure was not so much the result of the bad implementation of sound policies, but the logical outcome of a top-down approach's shortcomings. Policy implications for the public planning of industrial symbiosis in a mixed economy are then derived and the case for self-organization is found more compelling. The creation of more innovative institutions that will force firms to "internalize their externalities" while leaving them the necessary freedom to innovate is viewed as a more promising path towards increased sustainable reuse of industrial by-products. 


\section{Industrial Symbiosis : The Case for Market Coordination}

\section{Introduction}

Despite widespread beliefs on the incompatibility of market incentives and sustainable development, a number of recent case studies illustrate that inter-industry recycling linkages have spontaneously developed in Europe and North America in recent decades. Most prominent among these cases of "industrial symbiosis"1 is the Danish industrial town of Kalundborg [1,2], but similar processes have been observed in, among other places, Austria, Germany, Finland, and various American and European petro-chemical complexes [3,4,5,6]. These recycling networks are widely deemed the spontaneous result of several distinct, bilateral deals between company employees who sought to reduce waste treatment and disposal costs, to gain access to cheaper materials and energy, and to generate income from production residues. As Korhonen et al. [7, p. 179] point out in their recent review of the literature, "The emergence of industrial ecosystemtype development has been natural or spontaneous development. In other words, such diverse regional networks seem to self-organize rather than arise out of a specific planning process."

Despite the self-organizing nature of these linkages, a number of scholars, policy writers and development officials have suggested that public planning could actually foster greater levels of industrial symbiosis. For instance, when discussing Kalundborg, best-selling author Paul Hawken writes, "Imagine what a team of designers could come up with if they were to start from scratch, locating and specifying industries and factories that had potentially synergistic and symbiotic relationships" [8, p.63]. A similar case is also made by architects Sim Van Der Ryn and Stuart Cowen [9] in their best seller Ecological Design. As van Leeuwen and his collaborators put it, "While the Danish example has grown "organically", further diffusion of the phenomenon of eco-industrial parks will probably require deliberate strategies by local policy makers" [10, p.149]. On a larger scale, Robert Ayres suggested that the decentralized "pure" market system, such that each activity (firm) interacts with the others only by competitive buying and selling, does not optimise the use of by-products and secondary resources at the system level and that only "long-term central planning and coordination authority at the same level" will overcome this market failure [11, p.24]. The result of such thinking has been that, in Andrews'

1 In this paper, the terms "industrial symbiosis" and recycling linkages are used interchangeably. 
[12, p.369] words, in the "name of industrial ecology, some agencies are attempting, Gosplanlike, to account for flows of materials and energy through the local, regional, or national economy."

The appeal of central planning, whether at the national or local level, has proven extremely strong for more than a century. However, the worldwide implosion of centrally planned economies over the last fifteen years, their dismal environmental track record [14] and the past misapplication of systems approach in the public policy arena [15] do raise some questions about the potential effectiveness of a top-down approach to sustainability. The case on behalf of central or local planning of industrial symbiosis becomes even more problematic when one considers that such an approach was actually tried in Eastern Europe and proved to be a complete failure. To be sure, not all proposals to plan eco-industrial parks or other forms of industrial symbiosis involve full-scale public planning. Yet, in our opinion, the lessons learned from the failure of central planning considerably weaken the case on behalf of current pro-active approaches on the part of public officials.

The purpose of this paper is twofold. The first is to illustrate that industrial symbiosis proved much more widespread and successful in market economies than in centrally planned ones by comparing the very different cases of Victorian England and communist Hungary. The second is to suggest a theoretical explanation for this outcome that is derived from the so-called "Austrian" critique of central planning and to draw some policy implications for current policy making.

2 Of course, as Andrews points out, many industrial ecologists are not advocating central planning but are rather attempting "to introduce into the public discourse new information on environmentally significant flows (such as toxic materials and fossil fuels) in the hope of influencing many decentralized individual decision makers." This point is also made in more detail by Cohen-Rosenthal [13] in his discussion of "self-organizing vs. engineered systems." 


\section{Markets, Central Planning and Industrial Symbiosis}

\subsection{Industrial Symbiosis in Laissez Faire Victorian England ${ }^{3}$}

Though not a textbook example of a "pure" market economy, Victorian England is usually recognized as the era when the laissez faire doctrine enjoyed greater respectability and where markets were among the freest in human history [18]. As such, it probably provides as good a case study as any to look at the propensity of market economies to spontaneously generate (or not) industrial recycling networks. As it turns out, many Victorian commentators whose perspective spanned the ideological spectrum documented, or at least alluded to, the widespread spontaneous formation of industrial recycling networks.

While he deplored like many of his contemporaries the inability of entrepreneurs and public officials to create wealth out of human sewage, English resident Karl Marx observed in the third volume of his Capital (published posthumously by Friedrich Engels in 1894) that "the capitalist mode of production extends the utilisation of the excretions of production and consumption" and that "the so-called waste play an important role in almost every industry" [19, n.p.]. Another radical British economist, John Hobson, similarly observed that "new industrial arts owing their origin to scientific inventions and their practice to machinery arise for utilising waste products" and that "conspicuous examples of this economy are found in many trades. During the interval between great new inventions in machinery or in the application of power many of the principal improvements are of this order" [20, p.75]. Alfred Marshall, the most prominent British economist of the turn-of-the-century, similarly wrote "many of the most important advances of recent years have been due to the utilizing of what had been a waste product; but this has generally been due to a distinct invention, either chemical or mechanical” [21, p.232].

The fact that industrial waste reuse was deemed widespread by a large number of Victorian writers can probably be traced back to no small extent to the work of the journalist Peter Lund Simmonds (1814-1897). Although now largely forgotten, Simmonds was a prolific author on

\footnotetext{
3 For a more general assessment of the capacity of market economies to "close the loop" on industrial waste, see Desrochers $[16,17]$.
} 
technical and commercial topics. ${ }^{4}$ Beginning with the preparations leading to the Great Exhibition of 1851, Simmonds undertook a detailed compilation of the ways by which his contemporaries turned industrial waste into valuable inputs. His work culminated in an exhibit for the Bethnal Green Branch of the South Kensington Museum (henceforth, BGB) ${ }^{5}$ and in the writing of two very different editions of his book Waste Products and Undeveloped Substances. The first edition, published with much delay in 1862, covered the topic up to the early 1850 s. The revised version, first published in 1873, covered the two following decades.

Perhaps the most interesting aspect of Simmonds' 420 page compendium is that he already feared in 1862 that "the general subject treated of in this volume... is too extensive in its scope to be discussed successfully in detail here, since any one branch would of itself form a useful and interesting volume" [23, p.v]. This statement is even more remarkable in light of the fact that the first edition of Waste Products covers in 35 chapters topics ranging from cotton by-products to the waste of fisheries and "waste mineral substances."

Simmonds made clear in his writings that the recovery of industrial waste products was becoming generalized during his lifetime. He thus observed in the first edition of his book, "In every manufacturing process there is more or less waste of the raw material, which it is the province of others following after the original manufacturer to collect and utilize. This is done now, more or less, in almost every manufacture, but especially in the principal ones of the [United Kingdom] - cotton, wool, silk, leather, and iron. But new industries spring up from time to time, and out of the worn substances and waste of these much commercial wealth has yet to be drawn" [23, p.2]. He would reiterate this point in the revised edition of his book, "It may truly be said that there is scarcely any manufacture in which there does not remain, in the form of residue or waste, something which, though not suited for that special manufacture, has still a considerable economic value. And this may generally be usefully employed in some way or other. This is one of the characteristic and salient points of modern enterprise, not only to allow nothing to be wasted, but to recover and utilise with profit the residues from former workings" $[24$, p.4].

4 To my knowledge, Simmonds' only biographical treatment in the $20^{\text {th }}$ century is Greysmith [22].

5 The BGBM later became part of what is now the Victoria and Albert Museum. 
Simmonds also borrowed the "industry as nature" metaphor from chemist Lyon Playfair and used it on several occasions to point out that Victorian industrialists' behaviour was actually very close to what could be observed in what would later be called ecosystems. For example, he observed in the second edition of his book:

Our aim is now to utilise all things to the utmost possible extent. The uses to which they are turned are not always stale, flat, or unprofitable. We now produce valuable articles from what a few years ago was thrown away as nuisance. Once the raw material gets into the clutches of the manufacturer, it is tortured by a score of processes to yield up all its virtues. This system extends throughout all our modern actions in domestic and rural economy, and in our commercial undertakings...

Nothing comes amiss to our ingenuity. We consume our smoke, write and print on the remnants of our ragged shirts, and triumph over decomposition and stenches. Utilisation is the great law of Nature, and we are only following her teaching. The air we inspire gives us life, the poison we expire gives life to plants. She, true to herself, is never at a loss what to do with any of her elements. Man, in an artificial state of society, and in an enlightened age, also provides for converting all the material he uses into useful purposes. There must be no loss of anything once within his grasp [24, p.10].

In Simmonds' analysis, the rise of by-product recovery resulted from two main factors. The first were intense competitive pressures. As he pointed out in the Descriptive Catalogue of the Collection Illustrating the Utilization of Waste Products of the BGB:

Few among the minor tendencies of industries are more worthy of note than that shown in the utilization of waste materials. As competition becomes sharper, manufacturers have to look more closely to those items which may make the slight difference between profit and loss, and convert useless products into those possessed of commercial value $[25, \mathrm{p} .4]$.

Simmonds also observed that new technologies were essential in creating resources from byproducts and therefore wrote, "One of the greatest benefits that Science can confer on man is the rendering useful those substances which being the refuse of manufactures are either got rid of at great expense, or when allowed to decompose produce disease and death" [24, p.5]. Furthermore, "a large number of such are now used in various ways which were formerly regarded as offal, and cast away, but many others still exist inviting the ingenuity of men of science to find for them useful applications" [25, p.3]. 
While Simmonds' work illustrates the extent to which by-product reuse among different industries was widespread in his time, it does not imply, of course, that Victorian firms were more efficient or cleaner than current operations whose foundations are built on more than a century of subsequent innovations, or that the British environment was healthier a century ago than it is today. Nevertheless, it provides compelling evidence that industrial symbiosis was a widespread phenomenon in one of the most market-oriented economies in human history. As will now be illustrated, however, conscious policies to promote industrial symbiosis proved disastrous in later decades in centrally planned economies.

\subsection{Planning Industrial Symbiosis: The Case of Post-War Hungary}

While many authors praised the incentive structure of market economies for ensuring that industrial resource recovery was practiced on a large scale, the late $19^{\text {th }}$ century saw the emergence of a new intellectual perspective that indicted markets for their inherent wastefulness. The roots of this perspective can be traced to the evolution of socialist thinking during this period. The first champions of socialism had depicted their ideal society as small self-contained egalitarian communities, frequently dubbed "islands of socialism," but they were hard pressed to answer the classical economists' criticism that living in less productive autarky would tend to create islands of misery in a capitalist world and that it was very unlikely that many people would be attracted by such prospects. In trying to answer this critique, socialist intellectuals increasingly turned toward the idea that the accumulation of knowledge and the application of scientific methods through central planning could bring anarchic social processes under conscious control for the general good. Economic welfare would thus be maximized when a technocratic elite would be given control in a way that would insulate it from traditional market signals of profits and loss. Central planning, it was thought, would lead to production for use instead of profits, which would in turn rationalize production, eliminate waste, increase productivity, and end the struggles between rich and poor. What was needed was therefore worldwide central planning, or at any rate central planning on as large a scale as possible. These notions were relayed, refined and applied by numerous economists, industrial engineers, "scientific management" consultants and conservationists [26,27,28,29]. 
While many authors belonging to this line of thought wrote extensively on "wasteful production," relatively few had much to say on industrial by-product recovery. Indeed, the notion of "waste" used by these authors typically referred to, among other things, the waste that allegedly occurred in industrial plants as a result of the failure of their management to implement the principles of scientific management, the unnecessary duplication of productive units, the production of unnecessary goods, the great diversity of production methods, minor variations in finished goods in the same industry, seasonal layoffs, labour-management disputes, business guesswork resulting from bad government statistics, legal costs resulting from an inefficient judicial system and the large discrepancy between supply and demand in the uncoordinated marketplace.

Two books that were part of this literature but that dealt somewhat more significantly with (actual or potential) industrial by-products are the British engineering professor Henry J. Spooner's 1918 Wealth from Waste [30] and, to a lesser extent, the American journalist and popular writer Stuart Chase's 1925 The Tragedy of Waste [31]. Spooner devoted about 40 pages out of his 300-page book to by-product recovery, although his writing consists mostly of unreferenced anecdotes and a general plea for more scientifically organized research efforts in this respect. According to his analysis:

The marked success attending the spasmodic and sporadic attempts that have been and are being made to collect waste articles is a sure indication of the enormous amount of wealth awaiting organised collection and treatment. The municipalities have it in their power to render great services to the State by organising a complete system, including house-to-house calls by voluntary women helpers. But nothing of real importance is likely to be done on an extensive scale until such schemes are organised throughout the country from some State department, such as the Local Government Board [30, p.21].

Stuart Chase similarly identified a built-in "market failure" that precluded the widespread recovery of industrial waste, but that could be corrected through a more rational management of economic life.

Whenever material of any sort is burned down or thrown away, with it goes a certain number of chemical elements - oxygen, nitrogen, sulphur - in various chemical combinations, which may or may not be valuable, but which are always suspect until 
the chemist has reviewed them... It does not pay, of course, to save all - perhaps most - discarded material. But it pays more now than it did a generation ago, and the process is accelerating... The invariable question to be answered is whether the salvage is worth the cost of conversion. The trouble is that while no must often be the individual manufacturer's answer because he cannot finance large scale renovation, the answer of the whole community is often yes [31, p.261-2].

While public officials in Great Britain and the United States never embarked on a large scale central planning effort to close industrial loops, this idea was actually tried in the Eastern Bloc in the aftermath of the Second World War. One recent study by Hungarian-born sociologist Zsuzsa Gille [14] thus describes in much detail how during state socialism (1948-1989) Hungarian planners tried to institute a production-centred, preventative approach to industrial wastes that presents striking similarities to proposals that have been made in recent years in the name of industrial ecology and ecological modernization. These policies, however, failed to live up to their promises and were abandoned in recent years with market liberalization.

In the 1950's, the main emphasis was put on waste reuse. This focus led, among other things, to the creation of an elaborate hierarchical input and output quotas system of waste registration, collection, distribution and reuse. As a result, between 1950 and 1959, 34 central regulations on the collection, storage, delivery and price of waste materials were issued. The first waste law obliged companies generating certain types of waste to collect and offer them for transfer to other firms in accordance with quotas. According to Gille: "Subsequent laws prescribed which wastes were to be delivered to which company, how to calculate the price of wastes, what to do with hitherto unregulated waste materials, and how much material reward could be given to those who collected wastes beyond the planned amount" [14, p.206].

Waste also became a key issue around which the population was mobilized. The culmination of these campaigns was the Gazda movement, named after a metallurgical worker, Géza Gazda, who had invented a new way to reuse scrap metal. As Gille points out, however, these policies led to two unintended consequences. First, the reuse of waste materials required additional raw materials, energy and labor, which, along with most products, were all in short supply. As a result, collected wastes were often left rotting and rusting on factory yards. Second, reuse, even when it materialized, did not prevent recovered wastes from becoming trash because these early- 
recycled goods were in many cases not needed, and even chronic general shortages could not increase their appeal. According to Gille, "not only did the movement and waste policies fail to reuse wastes effectively, but they also strengthened the tendencies of the centrally planned economy towards wasteful production.... Furthermore, the waste quotas created an added incentive for workers and managers to produce with even higher waste ratios" [14, p.209] These unintended consequences were increasingly acknowledged and led to the revocation of the waste quotas by the end of the 1950s.

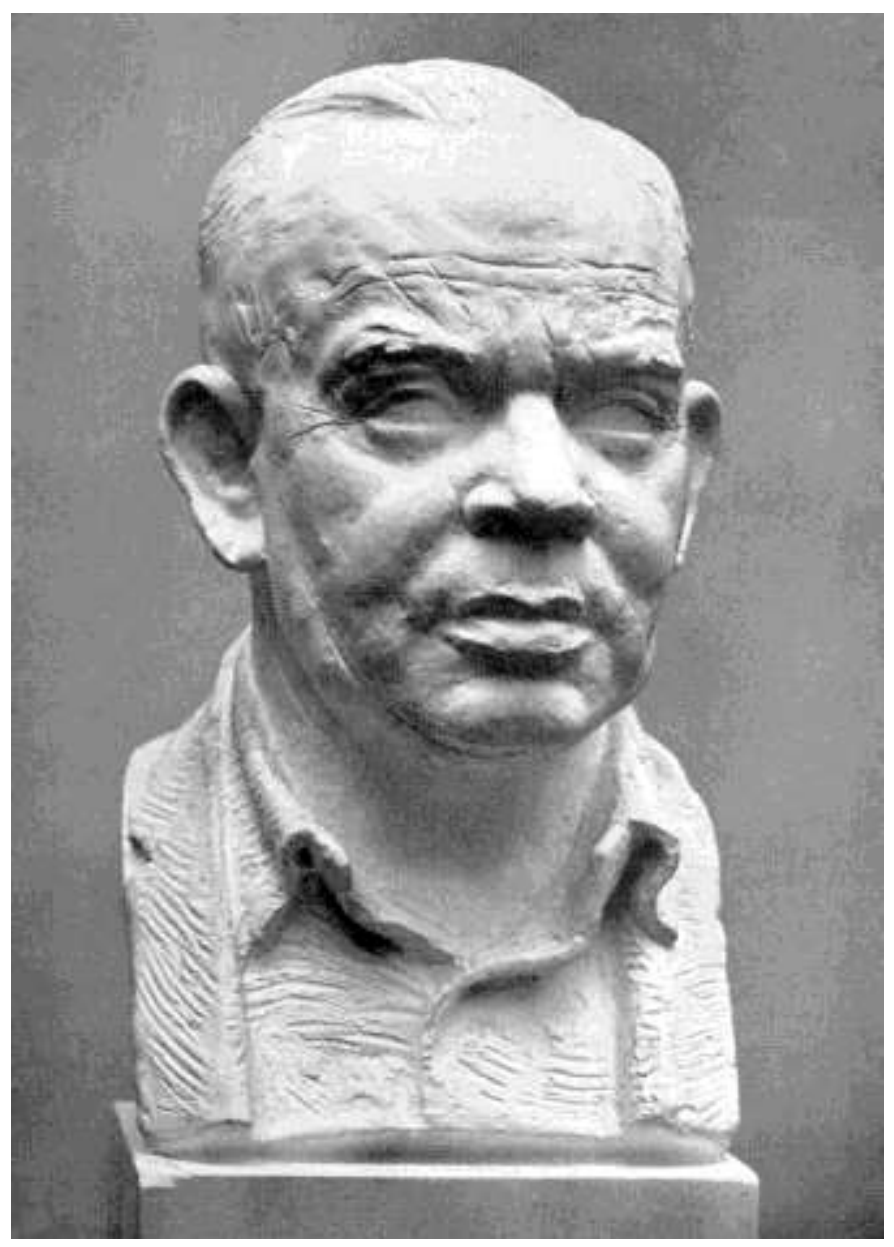

Bust of Géza Gazda by Lajos Petri (date unknown)

Source: Hungarian National Gallery and http://keptar.demasz.hu/keptar/english/p/petri/muvek/ 
The concept of waste as useful material nonetheless remained on the agenda of central planners in later years. According to Gille, from the mid-1970s, waste was increasingly seen as a cost of production and further policies, which are very similar to those that have been advocated in recent years in the name of sustainable development, were put in place with the aim of decreasing such cost. Among these were price increases for wastes, which made the collection of wastes more worthwhile, and a new opportunity for firms to calculate prices for recycled products as if they had used new raw materials for them. The reuse of waste also became the object of cost-benefit analyses. Funds were established to motivate firms to apply wasteconscious technologies and the state financed at least two-thirds of the costs of reuse facilities. Parallel to this change in the concept of waste, the relationship between the enterprises and the state also went through a transformation. Instead of centrally calculated waste quotas, enterprises were now free to decide which wastes they wanted to reuse, sell, treat, or dump, and they were meant to be motivated by the above-mentioned financial incentives. It was also in the 1980's that Hungarian waste policies first addressed waste problems as an issue of environmental pollution.

According to Gille, however, the "1981 Waste and Secondary Raw Material Management Programme did not achieve its stated goal of substantially increasing the portion of secondary raw materials among industrial inputs" [14, p.213], although it did help in finding uses for potentially dangerous wastes. These policies were later abandoned with the fall of the Iron Curtain.

These contrasting outcomes in terms of industrial symbiosis raise a number of issues for current policy prescriptions. On the one hand, individuals and firms in the market economy of Victorian

England seemingly proved successful at closing industrial loops without any "grand design" to this effect, while Hungarian central planners who openly attempted to achieve this goal were not. How can we reconcile these facts? While it could be argued that Hungarian planners did not try hard enough or set the wrong quotas, this answer does not seem plausible in light of the general failure of central planning wherever and whenever it was tried. A more convincing answer can be found, at least implicitly, in the so-called "Austrian" critique of central planning.

\section{The Austrian Critique of Central Planning and Industrial Symbiosis}




\subsection{The Austrian Critique of Central Planning}

The Austrian critique of central planning launched and was further elaborated during the socialist calculation debate that raged in economic circles in the 1920 s and 1930s. ${ }^{6}$ On one side of the debate were economists either trained or influenced by the Austrian tradition that developed following the publication in 1871 of Viennese economist Carl Menger's (1840-1921) Grundsätze der Volkswirtschaftslehre (Principles of Economics). "Austrian economists", as they would later be called, believed that socialism and central planning could not improve upon the economic performance of a regime of private property and free markets. ${ }^{7}$ On the other side were professional neoclassical economists who were critical of markets because of their perceived failures to achieve full employment, equitable income distributions and rational investment, and who wished to find some method of central planning that would duplicate the potential efficiency of free markets without suffering their shortcomings. By the mid-1940s, these neoclassical economists had come to argue that once the formal equations defining efficient equilibrium were in place, the allocation problem facing the central planner would be no different in principle from the one facing individual consumers: maximizing welfare by allocating the resources at hand on the basis of marginal equalities. Conventional opinion from then on held that the Austrians were wrong, that socialism was in fact possible and that central planning could be both more efficient and more equitable than the free-market. This perspective would be dominant for most of the next 40 years, until the disintegration of communism and the obvious economic failures of central planning required a re-evaluation and greater appreciation of Austrian arguments [35].

\footnotetext{
6 The term "socialist" is rather vaguely defined today, but at the beginning of the $20^{\text {th }}$ century its meaning was fullfledged central planning. Thus while the writings of Austrian economists questioned the feasibility of socialism, most of the time in this paper I will refer to their critique of central planning. For a compendium of the most important essays and books in this debate, see Boettke [32]. For more detailed accounts of the Austrian critique of planning, see Boettke [33] and Vaughn [34].

7 The Austrian school was originally divided into two strands. The first is sometimes referred to as "Austroliberalism," (in the classical or European sense of the word liberalism) whose tradition goes back to Carl Menger. At the beginning of the 1930s Ludwig von Mises, a member of the third generation of the school, was the undisputed (if only informal) leader of this group. The most prominent among the younger members were Friedrich August Hayek, Gottfried Haberler, and Fritz Machlup. The second and less coherent strand, which more closely followed the teachings of Friedrich Wieser, had a more reserved position towards free markets, in theory as in practice. Its best-known representative was Hans Mayer, and among the younger economists the most famous were Oskar Morgenstern, Alexander Gerschenkron, and Paul Rosenstein-Rodan. Today, the label "Austrian" is used almost exclusively to describe the heirs of the "Austroliberalism" tradition.
} 
Before getting to the core of the Austrian critique of planning, a few words must be said on the foundations of this school of thought. ${ }^{8}$ While it is sometimes regarded as the Austrian wing of the 1870s "marginalist" revolution in economics, the Austrian School had many characteristics which distanced it from the approaches of Stanley Jevons and Leon Walras that eventually gave rise to modern neo-classical economics. In time, Austrian economists came "to offer a reasoned description of human action, which is profoundly and constantly disequilibriating in the neoclassical lexicon, but which is continuously yielding to spontaneous order" [37, p.135]. Modern day Austrians, a small but still active community now mostly made up of American scholars, usually tend to view economics as the study of human action where humans are intentional beings who have purposes, who creatively apply means to bring desired goals into existence, and in the process discover various mutually beneficial transaction opportunities with their fellow humans that generate the network of relationships we call human society. Generally speaking, Austrian economists eschew the use of complex mathematical models in favor of a qualitative analysis of market processes where acting humans possess imperfect knowledge in a world of uncertainty. Most Austrians also believe that three basic methodological tenets should be adhered to: 1) methodological individualism; 2) methodological subjectivism; 3) theoretical attention should be on processes rather than equilibrium states.

In the Austrian perspective, planning is viewed as a universal fact of life that requires three elements that must somehow be solved: purpose, information and control. These "planning" actions can range from turning on a light switch to carrying out an entrepreneurial venture to getting a man to the moon and back. As Adelstein points out, "Though we often speak of planning as something done by abstract collectives, the purpose and cognition it demands make it clear that planning is done by people, not by groups or organizations as such... individual planning [is] what men and women do when they are free to pursue their own purposes, and central planning [is] the subordination, by whatever means and to whatever extent, of one or more individuals' purposes to those of the central planner" [38, n.p.] In the Austrian perspective, the real economic choice that had to be made was therefore not between the anarchic marketplace or central planning, but rather who's planning and for whom? Each member of society for himself or the central planners at the exclusion of everybody else?

8 For a more detailed survey of this school of thought, see Boettke [36]. 
While many other writers had raised the issues of incentives in a socialist system before the Austrians (often summarized by the quip "Who will take out the garbage in a socialist society?"), the Austrian critique went beyond the issues of incentives and the possibility of creating a new Homo sovieticus that would work as well for the common good as he would do for his own benefit - although it did address those issues. ${ }^{9}$ Instead, what the Austrians questioned was the ability of central planners to perform a rational allocation of scarce economic resources. In an article published in 1920 and in later writings, the economist Ludwig von Mises (1881-1973) argued that socialist planners - even if they were truly benevolent and wished only to help their subjects - could never achieve this goal because they had no rational basis for economic calculation [40,41]. In Mises' perspective, the rationality or irrationality of a resource use is to be decided on the basis of a comparison between alternative uses of that resource. Fallible men acting in a changing world must therefore choose among a very large number of imaginable and possible methods of production and attempt to use any unit of input in a project that is more important than any other project in which it could also have been employed.

Mises raised the following question: What is the standard of comparison? In terms of which criterion can or should we compare investment alternatives? He pointed out that a market economy could use the profitability criterion because, however imperfect they may be, market prices provide some "aid to the human mind" for comparing inputs and outputs before processing alternatives because they reflect the relative urgency of human wants. For all investments, entrepreneurs and managers can estimate the selling proceeds as well as the cost expenditure in terms of money prices. They can then compare the ratios that spring from these estimates. ${ }^{10}$ This procedure insures that, even though particular entrepreneurial ventures will always fail, in the long run having expenditures systematically exceed income will not hamper capital formation in a market economy.

\footnotetext{
9 Distinct from their purely economic criticism, Austrian economists also argued that centrally planned institutions would in time subvert the originally humane goals of socialist theorists to quite different priorities because in their efforts to enforce its plans, collectivist politics must inevitably become totalitarian in nature [39].

10 Of course, entrepreneurs are not somehow compelled to only look at profitability when they make their decisions. The point is that they can look at the profitability criterion, and that in the light of this criterion all investment alternatives in a market economy are indeed comparable.
} 
On the other hand, Mises argued, central planners were deprived of the very means of economic rationalism. To make his point clear, he granted the theoretical planners theoretical access to all the data about production that might be needed, except those that were generated by the market process. Mises pointed out that monetary calculation was simply out of the question, for money prices can only come into existence in market exchanges - and market exchanges presuppose the existence of at least two owners. Central planning, by definition, has only one owner of all means of production and therefore provides no means to calculate a profit rate for any investment project and to compare the profitability of different alternative investments. Far from overcoming the alleged "anarchy of production," central planning would actually produce more chaos than existed before its imposition. Boettke summarizes Mises' arguments in the following way: "In the world in which we live, economic decision-makers are confronted with an array of technologically feasible production projects, what economic calculation provides is a means to select from among these projects to assure that resources are employed in an economic manner. Waste, as a result, will be minimized as decision errors are continually detected and corrected by the aid of profit and loss accounting" [32, p.32]

It is also worth pointing out that Mises did not believe that some objective value could offer an alternative to the market discovery process as a guide to economic production. ${ }^{11}$ True, Mises observed, economic calculation could be dispensed with in a stationary economic system, but a stationary economic system could never exist in a world inhabited by purposeful human beings where some individuals were unhappy with the status quo. As he put it: "It should be already sufficiently clear from what has been said, that under Socialism, as under any other system, there could be no perfectly stationary state. Not only incessant changes in the natural conditions of production would make this impossible; quite apart from these, incessant dynamic forces would be at work, in changes in the size of the population, in the demand for commodities, and in the quantity of capital goods. One cannot conceive these factors eliminated from the economic system" [40, p.180].

11 Mises' targets were those most familiar to economists, such as Marx's concept of socially necessary labour time, but his critique could equally apply to the various measures of energy that were proposed as a substitute to monetary prices at the time [26]. 
Mises' main argument was supplemented in the 1930s by his protégé and future Nobel recipient, Friedrich A. Hayek (1899-1992), who argued that it is because of the necessary or inevitable ignorance of individuals that it is better to allow society to develop by spontaneous adjustment than to control it all by some central agency [42]. In short, a market economy would always be more effective than central planning because of its ability to use effectively the "tacit" knowledge of market participants through a decentralized process of learning by trial and error. The key point Hayek made was that much of the knowledge necessary for running the economic system is not scientific or technical (i.e., explicit), but rather "tacit" knowledge, which he defined as the idiosyncratic, dispersed bits of understanding of "circumstances of time and place" that individual acquire through past experience, practice and mistake. Hayek argued that this tacit knowledge could never be communicated to a central authority. On the other hand, it was used along the way in a market economy through a "discovery procedure" as individuals pursued their own ends. The central economic problem facing society was therefore not, as commonly expressed in textbooks, the allocation of given resources among competing ends, but rather a problem of "the utilization of knowledge not given to anyone in its totality" [42, p.78].

For Hayek, the voluntary operations of a market system generate a "spontaneous order" that is "the product of human action but not human design" and produce overall benefits unintended and mostly unforeseen by those whose actions bring it about. In Hayek's view, the socialists erred in failing to see that the economy as a whole is necessarily a spontaneous order and can never be deliberately made over in the way that the operators of a planned order, such as a firm, can exercise control over their organization. This is because planned orders can handle only problems of strictly limited complexity. Spontaneous orders, by contrast, tend to evolve through a process of natural selection, and therefore do not need to be designed or even understood by a single mind. Industrial symbiosis, as it evolved historically in numerous market economies [16, 17], would seem to fit neatly into Hayek's perspective. ${ }^{12}$

\subsection{Policy Implications of the Austrian Critique of Central Planning}

How relevant is a perspective that was shaped in a debate between polar cases of perfectly atomistic markets and comprehensive state planning - which have never existed in their

12 To my knowledge, neither Hayek nor any other Austrian ever addressed the issue of loop closing. 
"perfect" form 13 - for current efforts to plan industrial symbiosis and eco-industrial parks in mixed economies? ${ }^{14}$ While more empirical experimentation on the part of development officials and research into their projects might be needed before a definitive verdict can be reached, the Austrian critique of public planning offers some insights that do not bode well for the most comprehensive symbiosis planning efforts currently underway.

A first thing to keep in mind is that Austrians do not rule out central planning efforts by large organizations, otherwise they would be hard-pressed to explain the existence of large private firms with internal economies often comparable in monetary terms to those of small countries. While the management practices of these firms might sometimes be remote from the textbook ideal of a central planner, it cannot be denied that their managers have obviously found ways to achieve the coordination and control needed to use efficiently the human and material resources at their disposal. What this implies in the context of industrial symbiosis is that much "loopclosing" is and will be carried on within the confines of a particular plant or between plants belonging to the same firm or conglomerate. For example, large firms involved in wood production often recover theirs sawmills' leftovers and use them as an energy source and as an important input for their paper-making operations $[45,46,47,48]$. Similar loop-closing processes have been going on for quite some time in the petrochemical [1,5,49] and meat-packing [16] industries, among others. In such cases, the industrial ecology metaphor may perhaps distort the analytical framework of some analysts and policy makers, if only by leading them to believe that industrial processes have traditionally been more linear than they probably were.

Yet, the fact remains that in a modern economy each firm must continually strike a balance between buying and making various inputs. This is where Mises' point on the rational allocation of resources takes on special significance. Thus, in a dynamic and competitive market economy, the inputs and outputs of firms can be expected to change over time for both economic and technical reasons. For example, the rise in the price of a given input or the lowering of the production costs of substitutable products may affect the economic value of a particular kind of

13 The recent opening of Soviet archives has shed considerable light on the reality (or rather lack of reality) of central planning in the former Soviet Union [43].

14 The Austrian perspective was further elaborated in the context of a mixed economy by later writers [44].

However, for the purpose of this essay, the points raised by Mises and Hayek were deemed sufficient. 
waste. Similarly, new technologies may make traditional waste/inputs obsolete or, to the contrary, provide new and more lucrative markets for them. Competitive pressures will also entice firm and plant managers to reduce their waste flows or find more productive uses for their waste. Firms that are not innovative in this respect will in time go out of business, while more innovative competitors will put their resources to more profitable uses. Political disturbances will also, from time to time, affect inputs and markets. Public planners whose efforts are targeted at recruiting companies to fill a perceived void can therefore never be assured that the demand for a particular type of waste will remain constant over time. Instead, change will remain the only constant.

Perhaps the main shortcoming of comprehensive planning efforts with regards to industrial symbiosis is, however, the narrow perspective it entails. In short, planners will inevitably tend to look at firms and plants as primarily waste producers and/or waste users. Yet, by-product flows are but one dimension of the general planning effort necessary to run effectively a firm or a plant. Typically, private sector planners must factor in many variables in the conduct of their operations, such as finding adequate labor, material, and energy supplies, proximity to markets, quality of life and amenities, business climate, capital availability and the need of frequent faceto-face interaction. By-products will only be crucial, at least in terms of location decisions, if they are the most important inputs of a firm. In this case there would be no need for public planners to lure a waste-producing or receiving firm in a particular location because economic incentives would be sufficiently important to justify search and location procedures on the part of the firm's employees themselves.

Hayek's "knowledge" argument is also enlightening on many counts. First, it reminds us of the fact that the type of knowledge that public planners and firm employees both possess and can discover will most likely be of a different nature. Thus the knowledge that most public planners can acquire is essentially a synthesis of what they learn from individuals working within firms about a very large set of by-products. They can then classify this information according to broad standard industrial classification schemes and look for possible matches by dwelling on the most well known uses of these by-products. In contrast, in a private firm, employees who have to deal with by-products will typically look at a much smaller set of waste products. In so doing, they 
can explore more reuse possibilities and contact a larger number of potential customers. Kincaid's [50] by-products survey of producers located in and around North Carolina's Research Triangle area is illustrative in this respect when she points out the following:

Another means of increasing creative thinking about by-products was to foster interaction with people from outside individual facilities. When the interviewers sat down to review the survey booklet with facility representatives, the discussion usually resulted in the identification of promising items to add to survey responses. When the interviewer was able to take a tour of the plant, yet more reusables were usually identified. The creative process was further boosted by discussions between two or more potential partners.

Kincaid went on to identify examples of brainstorming that resulted from such meetings where direct interaction between technologists lead to new potential ideas and to the discovery of overlooked possibilities. For instance,

Two representatives from a tool manufacturing company visited an amino acids manufacturing plant to discuss a potential acids partnership. After they determined that an acids exchange might be feasible, the tool manufacturing company representatives asked, "What also do you have that we might be able to use?" This query resulted in a walk to where waste fiberboard drums were stored. These drums were lined with plastic bags, and they were originally packed with pouches of desiccant inside to keep the contents dry. The tool manufacturing representative thought his company might be able to use some of the drums, and the two men started enthusiastically brainstorming about who else might be able to use the plastic bags and desiccant pouches. The tool manufacturer suggested the Adopt-A-Highway program for the plastic bags and marinas for the desiccant [50, p.93].

Another aspect of Hayek's knowledge argument is that even within an industry, most individuals are likely to know only a particular aspect of the greater division of labor to which they belong. This is why historically economic development has always led to a greater and increasingly complex division of labor and to the rise of firms that specialized in wholesale or retail. Thus, while firms operating in niche markets can often specialize in both the production and the distribution of their goods, it is typically the case in extended markets that specialized firms emerged to distribute various kinds of goods and in the process developed a particular kind of expertise in gathering specific knowledge of market conditions and participants. This pattern was also predominant for by-products, as waste traders (dealers and brokers) in various commodities have played an important role in this respect for more than a century [51]. A prime example is 
the secondary metals industry, which has long thrived almost unnoticed. As an editorial from the trade publication American Metal Market put it almost 40 years ago, "Despite the fact that the secondary materials industries have been making a monumental contribution to the nation and its consumer-oriented economy, there are few among the public at large who realize it. They either aren't being told about the essential and beneficial role of the secondary materials industries, or they aren't told enough" [quoted in 52, p. 16]. This void in historical research has since been partly filled by Maher [51] in his detailed examination of the formation of the American Scrap Steel Industry between 1870 and 1933. Among other sources, he quotes an industry specialist who wrote in 1925 that "ordinarily railroad scrap is offered in lists showing the tonnage of various grades and bids are made by dealers, who serve it in turn to their customers. This is more convenient than it would be were railroads to conduct the business of selling to the actual customer" [51, p. 101]. According to Maher, only one big steel producer, Bethlehem Steel, ever made a serious attempt to bypass the waste dealers in collecting scrap because other steel producers realized that they could not outperform them. The role that public planners give themselves in terms of industrial symbiosis has therefore long been filled by various firms specializing in the acquisition of the particular knowledge of "time and place" related to byproducts.

\section{Conclusion}

After experiencing a lifetime of socialism, the Soviet philosopher Alexander Tsypko could say with certainty that during "70 years of socialist experimentation in Russia, not one major problem that the country was facing in 1917 has been solved" [53, p.290]. The reason for that failure, according to the Ukrainian physicist Igor Yukhnovsky, was not hard to discern: "When something is ruled from the center, the optimization of life is impossible" [quoted in 54, p. 441].

The collapse of central planning is perhaps the main economic lesson of the $20^{\text {th }}$ century. Among the various theoretical explanations put forward to make sense of it, the most satisfactory seems to be the critique developed from the 1920s onward by writers belonging to the so-called "Austrian School of Economics." In essence, Austrians argued that a number of problems, contradictions, inconsistencies and obstacles awaited comprehensive planning schemes. Most important among these were three factors: 1) the lack of incentives by individuals to invest their 
energies and their talents in producing goods that other people are willing to pay for; 2) the difficulty of allocating resources rationally in the absence of a price mechanism or when prices have been distorted by various policies; 3) the inability of a centrally planned system to take advantage of the information that individuals possess about the special productive characteristics of the people and equipment with which they work, as well as information about the demands for goods and services in their locality.

Where others saw chaos, Austrians viewed markets as spontaneous orders that emerged on a foundation of private property rights, prices and a decentralized trial-and-error process of discovery and improvement. Industrial symbiosis, as it historically evolved spontaneously in market economies, provides a good illustration of processes that are "the result of human action, but not of human design." Its failure in centrally planned economies, on the other hand, similarly provides a powerful vindication of Austrian insights. Despite the fall of the Berlin Wall and the progress made in recent decades by market-oriented economies, many analysts still view market coordination as inherently chaotic. It is therefore not surprising that most interpretations of the emergence of the Kalundborg industrial symbiosis describe it as a fortuitous accident rather than a typical pattern of outcome that resulted from a particular set of historical and geographical circumstances. Kalundborg and other spontaneous cases of industrial symbiosis have therefore led to more calls for comprehensive planning exercises rather than a greater appreciation of spontaneous orders.

In the end, the case on behalf of the public planning of industrial symbiosis rests on an insufficient appreciation of some basic features of market economies and typical pitfalls of central planning. On the one hand, it presupposes that in a market economy firms have more incentive to cover the costs of by-product disposal than to eliminate them at the source or find new markets for them. It also requires firms' employees to lack incentives or to be unable to gather as much useful information on loop closing possibilities as public planners. Both postulates are manifestly false, on logical as well as empirical grounds. Public planners must also ignore to a large extent the dynamic nature of a market economy and the constant changes that it brings in the allocation of inputs and outputs, including by-products. Finally, it is doubtful that the knowledge that planners can gather will ever be as extensive as the knowledge of people who 
are directly confronted with particular problems and therefore more likely to find or invent opportunities.

Another problematic feature of the case for central planning is that it almost invariably results from a propensity to transfer the idea of planning from the mostly closed system of an individual enterprise to the much more open system of an economy. As Andrews puts it, "An engineered system has a purpose, whereas a non-engineered system does not. One can optimize a system that has a purpose, whereas one can only influence other system types. People who have the engineering impulse will try to analyze and change any system they don't like, even if it was not originally an engineered system" [15, p.39].

In this context, what should be the role of economic development officials and academics who would like to promote industrial symbiosis and a more efficient use of resources? Perhaps first and foremost to promote policies that will remove obstacles to industrial resource recovery, such as price-distorting subsidies that discourage recycling [55] and regulations that prevent the re-use of by-products [56,57,58,59], and by educating the public to the benefits of industrial symbiosis. As such, more emphasis should probably be put on the development of institutions that would more effectively force firms to "internalize their externalities" while leaving them the necessary freedom to develop new and profitable uses for by-products. ${ }^{15}$

\section{References}

1. Ehrenfeld J, Gertler N. Industrial ecology in practice: the evolution of interdependence at Kalundborg. Journal of Industrial Ecology 1997; 1(1):67-79.

15 The movement away from a property-right based framework of laws dealing with pollution in English-speaking countries will illustrate the nature of the problem. Traditionally, pollution problems in English-speaking countries were handled through the common law doctrines of negligence, trespass, nuisance and strict liability for abnormally dangerous conditions and activities. Liability was thus imposed whenever harm resulting by a pollutant could be demonstrated, based on scientific evidence. Unlike a regulatory system where specific standards of conduct are set and enforced, such a liability system mandated no specific conduct but allowed private parties both to recover monetary damages for harm caused and gain an injunction against offenders who did not or could not reduce emissions to a non-harmful level. Unlike modern environmental regulation, this common-law approach did not establish an arbitrary distinction between a useful material and a waste. A case has been made that many environmental problems in the last century resulted not so much from the failure of this system, but rather from the facts that torts such as nuisance claims were progressively stripped of their deterrent ability by a number of prodevelopment decisions handed down in the nineteenth century. The development of statutory law also often intentionally legalized pollution by preventing injunctions. For a more detailed discussion of these and other environmental policy failures, see Anderson and Leal [60] and Meiners and Morris [61]. 
2. Chertow MR. Industrial symbiosis: literature and taxonomy. Annual Review of Energy and the Environment 2000;25:313-337.

3. Schwarz EJ, Steininger KW. Implementing nature's lesson. The industrial recycling network enhancing regional development. Journal of Cleaner Production 1997;5(1/2):47-56.

4. Korhonen J, Wihersaari M, Savolainen I. Industrial ecology of a regional energy supply system: the case of Jyväskylä region, Finland. Greener Management International 1999;26:5767.

5. Venta GJ, Nisbet M. Opportunities for industrial ecological parks in Canada. Case study of Sarnia-Lambton industrial complex. Ottawa: Environment Canada, 1997.

6. Desrochers P. Cities and industrial symbiosis: some historical perspectives and policy implications. Journal of Industrial Ecology 2002; 5(4):29-44.

7. Korhonen J, Niemeläinen H, Pulliainen K. Regional industrial recycling network in energy supply - the case of Joensuu City, Finland. Corporate Social Responsibility and Environmental Management 2002;9:170-185.

8. Hawken P. The ecology of commerce. New York: Harper Business, 1993.

9. Van Der Ryn S, Cowan S. Ecological design. Washington: Island Press, 1996.

10. Van Leeuwen MG, Vermeulen WJV, Glasbergen P. Planning eco-industrial parks. An analysis of Dutch planning methods. Business Strategy and the Environment 2003;12:147-162.

11. Ayres RU. Toward zero emissions. Is there a feasible path? INSEAD Working Paper No. 97/80/EPS.

12. Andrews CJ. Putting industrial ecology into place: evolving roles for planners. Journal of the American Planning Association 1999;65(4):364-75.

13. Cohen-Rosenthal E. A walk on the human side of industrial ecology. American Behavioral Scientist 2000; 44(2): 245-264.

14. Gille Z. Legacy of waste or wasted legacy? The end of industrial ecology in post-socialist Hungary. Environmental Politics 2000; 9(1):203-231.

15. Andrews CJ. Restoring legitimacy to the systems approach. IEEE Technology and Society Magazine 2000;19(4):38-44.

16. Desrochers P. Market processes and the closing of 'industrial loops': a historical reappraisal. Journal of Industrial Ecology 2000; 4(1):29-43. 
17. Desrochers P. Industrial ecology and the rediscovery of inter-firm recycling linkages: historical evidence and policy implications. Industrial and Corporate Change 2002; 11(5):10311057.

18. Paul EF. Laissez faire in nineteenth-century Britain: fact or myth?. Literature of Liberty 1980; 3(4):1-71. In http://www.econlib.org/library/Essays/LtrLbrty/fplLNB.html

19. Marx K. Capital. Volume III, 1894, non-paginated. In http://csf.colorado.edu/cgibin/mfs/24/csf/web/psn/marx/Archive/1894-C3/Part1/ch05.htm (Visited on August 10, 2003).

20. Hobson JA. The evolution of modern capitalism. A study of machine production. New York: Charles Scribner's Sons, 1917[1894].

21. Marshall A. Principles of economics. $8^{\text {th }}$ edition. London: MacMillan, 1986 [1920/1890].

22. Greysmith D. The empire as infinite resource: the work of P. L. Simmonds (1814-1897). Journal of Newspaper and Periodical History 1990;6(1):3-15.

23. Simmonds PL. Waste products and undeveloped substances; or, hints for enterprise in neglected fields. London: Robert Hardwicke, 1862.

24. Simmonds PL. Waste products and undeveloped substances. A synopsis of progress made in their economic utilisation during the last quarter of a century at home and abroad. $3^{\text {rd }}$ edition. London: Hardwicke and Bogue, 1876 [1873].

25. Descriptive catalogue of the collection illustrating the utilization of waste products. Bethnal Green Branch of the South Kensington Museum. London: George E. Eyre and William Spottiswoode for Her Majesty's Stationery Office, 1875.

26. Akin WE. Technocracy and the american dream. The technocrat movement, 1900-1941. Berkeley: University of California Press, 1977.

27. Jordan JM. Machine-age ideology. Social engineering and american liberalism, 1911-1939. Chapel Hill (NC): University of North Carolina Press, 1994.

28. Riukuletho S. The concepts of luxury and waste in american radicalism, 1880-1929. Helsinki: Finnish Academy of Sciences and Letters, 1998.

29. Scott, JC. Seeing like a state. How certain schemes to improve the human condition have failed. New Haven: Yale University Press, 1998.

30. Spooner HJ. Wealth from waste. Elimination of waste a world problem. London: G. Routledge, 1974[1918].

31. Chase S. The tragedy of waste. New York: MacMillan, 1926[1925]. 
32. Boettke PJ, editor. Socialism and the market. The socialist calculation debate revisited. 9 volumes. London: Routledge, 2000.

33. Boettke PJ. Calculation and coordination. Essays on socialism and transitional political economy. New York: Routledge, 2001.

34. Vaughn K. The socialist calculation debate. In: Boettke PJ, editor. The Elgar companion to austrian economics. Aldershot: Edward Elgar Publishing; 1994, p. 478-84.

35. DeLong JB. "Forests, trees, and intellectual root". A review of Scott J. Seeing like a state. How certain schemes to improve the human condition have failed. New Haven: Yale University Press, $1998 . \quad$ In $\quad$ http://www.j-bradforddelong.net/Econ_Articles/Reviews/seeing_like_a_state.html (Visited on August 5, 2003)

36. Boettke PJ, editor. The Elgar companion to austrian economics. Aldershot: Edward Elgar Publishing, 1994.

37. Sommer JW. Unifying Themes in Non-Mainstream Economics: A Speculation. In Campel, $\mathrm{AB}$, editor. Dissipative strukturen in integrierten systems. Baden-Baden: Nomos VerlagsgesellSchaft; 1989. p. 133-144.

38. Adelstein R. Knowledge and power in the mechanical firm: planning for profit in austrian perspective. Review of Austrian Economics, forthcoming.

39. Hayek FA. The road to serfdom. Chicago: University of Chicago Press, 1944.

40. Mises LV. Socialism. An economic and social analysis. Indianapolis: Liberty Classics, 1981[1922].

41. Mises LV. Human action. A treatise on economics. Irvington (NY): Foundation for Economic Education, 1996[1949].

42. Hayek, FA. Individualism and economic order. Chicago: University of Chicago Press, 1948.

43. Lazarev V, Gregory PR. The wheels of a command economy: allocating soviet vehicles. Economic History Review 2002;55(2):324-348.

44. Ikeda S. Dynamics of the mixed economy. Toward a theory of interventionism. New York: Routledge, 1997.

45. Haygreen JG, Bowyer, JL. Forest products and wood science. An introduction. $3^{\text {rd }}$ ed. Ames (IA): Iowa State University Press, 1996.

46. Juslin H, Hansen E. Strategic marketing in the global forest industries. Corvallis (OR): Authors Academic Press, 2002. 
47. Wernick IK, Waggoner PE, Ausubel JH. Searching for leverage to conserve Forests. The industrial ecology of wood products in the United States. Journal of Industrial Ecology 1997;1(3):125-145.

48. Korhonen J, Wihersaari M, Savolainen I. Industrial ecosystem in the Finnish forest industry: using the material and energy flow model of a forest ecosystem in a forest industry system. Ecological Economics 2001;39:145-161.

49. Chapman K, Walker D. Industrial location. New York: Basil Blackwell, 1987.

50. Kincaid J. Industrial ecosystem development project report. Research Triangle Park (NC): Triangle J Council of Government, 1999.

51. Maher JW. Retrieving the obsolete. Formation of the american scrap steel industry 18701933. Doctoral dissertation (Geography), University of Maryland, 1999.

52. Lipsett CH. The fabulous Wall Street scrap giants. New York: Atlas Publishing Company, 1969.

53. Tsypko A. Revitalization of socialism or restoration of capitalism? Cato Journal 1991;11(2):285-292.

54. Dorn JA. The collapse of communism and post-communist reform. In Boettke PJ, editor. The Elgar companion to austrian economics. Aldershot: Edward Elgar Publishing; 1994. p. 440-447.

55. De Moor A, Calamai P. Subsidizing Unsustainable Development: Undermining the Earth with Public Funds, San Jose: Earth Council, 1997. In http://www.ecouncil.ac.cr/econ/sud/subsidizing_unsd.pdf (Visited on August 6, 2003).

56. Gertler N. Industrial ecosystems. Developing sustainable industrial structures. M.S. Thesis, Technology and Policy, Massachusetts Institute of Technology, 1995. In http://www.sustainable.doe.gov/business/gertler2.shtml (Visited on August 6, 2003).

57. Davies JC, Mazurek, J. Pollution Control in the United States. Evaluating the System. Washington, D.C.: Resources for the Future, 1998.

58. Swift B. Barriers to environmental technology innovation and use. Washington, D.C: Environmental Law Institute, 1998. In http://www.elistore.org/reports detail.asp?ID=440. (Visited September 8, 2003).

59. Volokh A. Recycling hazardous waste. How RCRA has recyclers running around in CERCLAs. Policy Study No. 197. Los Angeles: Reason Foundation, 1995. In http://www.rppi.org/ps197.pdf. (Visited September 8, 2003).

60. Anderson TL, Leal DR. Free market environmentalism. $2^{\text {nd }}$ ed. New York: Palgrave, 2001. 
61. Meiners RE, Morris AP, editors. The common law and the environment. Rethinking the statutory basis for modern environmental law. New York: Rowan \& Littlefield, 2000. 